AperTO - Archivio Istituzionale Open Access dell'Università di Torino

The Role of the International Financial Institutions in Fragile and Conflict-Affected Countries

This is a pre print version of the following article:

Original Citation:

Availability:

This version is available http://hdl.handle.net/2318/1660456

since 2018-02-21T18:43:50Z

Publisher:

Springer - Giappichelli

Published version:

DOI:10.1007/978-3-319-72293-1

Terms of use:

Open Access

Anyone can freely access the full text of works made available as "Open Access". Works made available under a Creative Commons license can be used according to the terms and conditions of said license. Use of all other works requires consent of the right holder (author or publisher) if not exempted from copyright protection by the applicable law. 


\title{
The Role of the International Financial Institutions in Fragile and Conflict-Affected Countries
}

\author{
AQ1 \\ Annamaria Viterbo 1禺 \\ Emailanna.viterbo@unito.it \\ 1 Department of Law, University of Torino, Torino, Italy
}

\section{Abstract}

Starting from Paul Collier's assumption that 'economic development may be the true exit strategy for international peacekeeping', the chapter describes the evolution of the international financial institutions' engagement with fragile and conflict-affected States (FCSs).

On the one hand, the World Bank initially engaged with post-conflict countries by only providing emergency recovery assistance. At the end of the 1990s, however, emergency assistance was completed by a specific policy on development cooperation in conflict-affected States. Nowadays, the IDA plays a central role in providing assistance to FCSs.

On the other hand, the IMF has always engaged with post-conflict countries through its traditional instruments (surveillance, staff monitored programs, technical and financial assistance). However, despite recognizing their specific needs and challenges, the Fund did not establish an ad hoc facility to provide financial assistance for FCSs differentiating these countries from other low- or middle-income members States.

In cenclusion the The study provides an analysis of IFIs policies and activities and advocates that there is an urgent need to intensify cooperation among development partners in FCSs.

\section{A Changing Theoretical Understanding of the Linkages Between Conflict, Security, Development and Sustainable Peace}

At the end of the 1990s, the research department of the IBRD, under the direction of Paul Collier, started to investigate the economic causes and consequences of conflicts (whether civil wars or international armed conflicts).

The IBRD studies demonstrated that post-conflict countries are affected by institutional and policy implementation weaknesses and are more prone to fall into a vicious circle of conflict and instability (the so-called 'fragility trap'). ${ }^{1}$ Low levels of income and rate of growth increase the risks of conflict.

Therefore, economic development is critical to prevent lapse or relapse into conflict. According to Collier, this suggests that "economic development may be the true "exit strategy" for international peacekeeping'. 
Collier's studies paved the way for a deeper understanding of the challenges posed by fragile and conflictaffected States (FCSs), where the loss of lives and human suffering are often accompanied by humanitarian crises, ethnic tensions, violent crimes, inequality and exclusion, destruction of infrastructures, pillaging of natural resources, corruption and a long-lasting disruption of the national economy.

In post-conflict countries, weak institutions and governance substantially impair recovery and the ability to deliver basic social services. After initial spikes, ${ }^{3}$ economic growth tends to be difficult to sustain and stagnation increases the likelihood of relapses. Moreover, the negative spill-overs caused by the spreading of conflict, refugee flows, epidemics, as well as barriers to trade and investment are likely to be suffered also by neighbouring countries.

FCSs tend to receive considerably less external assistance than other low-income countries. Overcoming their deep-seated capacity constraints and moving to sustained stability and growth requires long-term support and the coherent, coordinated and complementary engagement of the international community.

In the 1990s, despite growing recognition of the FCSs' unique challenges, the international financial institutions (IFIs) preferred to address their needs mainly through emergency assistance, broadening the scope of policies originally intended for natural disasters. ${ }^{4}$ Shocks caused by a conflict were viewed as requiring a relatively short period of assistance before a standard IMF arrangement or World Bank ${ }^{5}$ loan could be negotiated.

The IFIs proved also very careful in avoiding overstepping the UN and other organizations. They were ready to provide immediate and short-term financing within the limits of their mandates (where they had a comparative advantage), but explicitly underlined that humanitarian relief, peace-making and peacekeeping remained responsibility of other actors.

However, in some cases, the IFIs played a relevant role in the economic reconstruction of post-conflict countries (like in the case of Afghanistan, East Timor, Iraq and Kosovo). ${ }^{6}$ Deep economic and regulatory reforms were also promoted through technical assistance programs. ${ }^{7}$

At the beginning of the new millennium, the World Bank started to facilitate State- and peace-building, financing the disarmament, demobilization and reintegration of ex-combatants, as well as mine survey and awareness projects.

This development (unparalleled in the IMF practice) reflected a growing consensus on the principles that should guide the engagement of international organizations and donors in FCSs.

In 2005, the UN Peacebuilding Commission ${ }^{8}$ was established to ensure that the efforts of the international community in assisting post-conflict countries were carried out in a coordinated, integrated and effective manner.

In 2007, the OECD endorsed the Principles for Good International Engagement in Fragile States and Situations: a set of guidelines for actors involved in development co-operation, peace-building, Statebuilding and security in FCSs.

In 2011, the Group of Seven Plus countries $(\mathrm{g} 7+)^{9}$ and the International Dialogue on Peacebuilding and Statebuilding ${ }^{10}$ adopted The New Deal for Engagement in Fragile States, a set of principles guiding international engagement in conflict-affected States. ${ }^{11}$ 
The same year, the World Bank published the World Development Report 2011: Conflict, Security and Development, calling for a paradigm shift in the way post-conflict assistance had been provided. The Report stipulates that the legacy of violence, weak institutions and the multiple challenges plaguing FCSs cannot be resolved by short-term solutions and in the absence of legitimate institutions that provide people with security, justice and jobs. ${ }^{12}$

The following paragraphs describe the evolution of the World Bank and IMF engagement with FCSs until recent days.

\section{The World Bank’s Involvement in Conflict-Affected States}

The original mission of the IBRD consisted in fostering economic development, assisting in the reconstruction of war-torn Europe and favouring the transition to a peace-time economy. ${ }^{13}$

Shortly after its foundation, though, under the impact of the US bilateral aid program to Western Europe (the European Recovery Program launched in 1948), the IBRD essentially turned away from its reconstruction mandate to become primarily a development agency.

After the foundation of the International Development Association in 1960 and until the 1990s, the World Bank engaged in conflict-affected States only occasionally and consistently with the prohibition to interfere in the political affairs of member States (IBRD Articles, Article IV.10, IDA Articles, Article V.6). ${ }^{14}$

Initially, the Bank engaged with post-conflict countries only by providing emergency recovery assistance. At the end of the 1990s, however, emergency assistance in FCSs was completed by a specific policy on development cooperation in conflict-affected States.

Gradually, Operational policies (OP) and Bank procedures (BP) on both emergency assistance and development cooperation in FCSs were included in the WB Operational Manual ${ }^{15}$ and regularly reviewed.

While OPs delineate what are the aims and purposes of the World Bank activities in each sector, BPs set forth the procedural aspects related to the implementation of the OPs. They can be considered internally binding instruments of a quasi-administrative nature ${ }^{16}$ : the Bank staff is required to abide by them, they are incorporated in loan and credit agreements and private parties can 'enforce' them through the accountability mechanism of the Inspection Panel.

This chapter describes the evolution of the World Bank policies towards FCSs starting from the analysis of the Operation Manual and concludes with an assessment of recent practice.

\subsection{From the Bank’s Original Reconstruction Mandate to Emergency Recovery Assistance}

In the 1970s and 1980s, lending for emergency recovery grew significantly and in 1984 the Guidelines for Bank pParticipation in + Reconstruction pProjects AAfter ADisaster were adopted (Operational Policy Note 10.07). The Guidelines established procedures for emergency lending in cases of natural disasters; even though they did not mention war, they referred to man-made disasters.

In 1989 the Guidelines were replaced by Operational Directive 8.50 (OD 8.50), which in 1995 was 
transformed into Operational Policy 8.50 on Emergency recovery assistance (OP 8.50) without major conceptual changes. ${ }^{18}$

Under OP 8.50 a country could have requested assistance from the Bank when struck by an emergency that had seriously dislocated its economy and for which a quick response from the government was needed. A situation of emergency was defined in footnote 2 as 'an extraordinary event of limited duration such as a war, civil disturbance, or natural disaster'. Economic crises or shocks were excluded.

The Bank provided assistance aimed at restoring assets and production levels in the disrupted economymainly through an Emergency Recovery Loan (ERL) - , but not consumption or relief, ${ }^{19}$ which was considered outside the Bank's mandate.

Notably, to facilitate a timely and rapid response to emergency situations, the policy discouraged the application of conditionality unless directly related to the emergency recovery activities and to prevention and mitigation programs. ERLs in fact were not intended to address long-term economic or institutional problems and did not include any kind of conditionality linked to macroeconomic policies.

OP 8.50 also recommended coordination with the IMF on quick disbursement of loans as well as with other donors to design a shared recovery assistance strategy.

\subsection{Operational Policy 8.00: Rapid Response to Crises and Emergencies}

After more than 20 years from the date OP 8.50 was adopted, the World Bank decided to revise its framework for lending in emergency situations. According to the outcome of the review exercise, OP 8.50 was affected by serious flaws and its effectiveness was limited. ${ }^{20}$ The definition of emergency was deemed too focused on natural disasters and therefore too narrow. Priority to physical reconstruction of infrastructure did not enable the Bank to effectively address the diverse borrower's needs (and, in particular, the immediate needs of disaster victims). Overall, the policy did not provide the Bank with sufficient means to assist countries in the critical early stages of recovery, or with enough flexibility to cooperate with other international donors in implementing comprehensive recovery programs.

To address these concerns, in 2007, the Executive Directors adopted a new policy on emerging lending (Operational Policy 8.00 on Rapid Response to Crises and Emergencies), ${ }^{21}$ replacing OP 8.50. This policy is still operative today.

A key novelty of OP 8.00 is a broader definition of emergency that allows the Bank to provide a rapid response to a country's request to address 'an event that has caused, or is likely to imminently cause, a major adverse economic and/or social impact associated with natural or man-made crises or disasters'. 22

Support can be provided to pursue a wider set of objectives. Apart from rebuilding and restoring physical assets, Bank assistance may be directed at the restoration of means of production, economic activities and essential services; the establishment and/or preservation of human, institutional and social capital (including the economic reintegration of vulnerable groups); capacity building, disaster management, risk reduction and crisis prevention; and, most notably, the facilitation of peace-building.

It is worth mentioning that the legal department of the Bank carefully evaluated the opportunity to include a peace-building objective in OP 8.00. According to the legal opinion delivered at the time, ${ }^{23}$ under the new policy the Bank would continue to provide assistance within the limits of its economic and development mandate, with other organizations, in particular the United Nations, leading the international 
community's support in peace-making, peace-keeping or humanitarian aid. Activities outside the Bank's traditional core competencies - such as relief, security and peace-building - could be delivered, at a country's requests, only in partnership with other organizations or donors and through integrated recovery programs.

Accordingly, OP 8.00 was based on the premises that the Bank's activities should remain within its mandate, focusing on its core development and economic mission and that appropriate partnership agreements should be established with the UN and other development partners.

The inclusion of the goal to 'facilitate peace-building' reflected growing consensus that there exists a continuum between humanitarian relief, emergency and medium to long-term development assistance and sustainable peace.

In 2000-2007, the Bank approved, on average, 33 emergency operations per year. The majority of these emergency lending programs addressed post-conflict situations in Africa. Loans were provided for postconflict stabilization and aimed at the restoration of social and human capacity (for example, the Bank provided financing for social service delivery programs, the reintegration of ex-combatants or the protection of vulnerable communities). In fewer cases, lending had the objective of rebuilding and restoring physical assets, restoring the means of production, essential services and State capacity.

In the period 2007-2008, the Bank approved post-conflict rapid response operations in all the countries where a peacekeeping mission was being deployed: in the Central African Republic, the Democratic Republic of Congo, Côte d'Ivoire, Liberia and Sudan. In the cases of Côte d'Ivoire and Uganda, loans projects explicitly aimed at supporting peace-building and the implementation of the peace agreements. ${ }^{24}$ In so doing, the Bank did not subject its lending to compliance with peace agreements (the so-called 'peace conditionality'), but aimed at contributing to the prevention of further conflict and improving the chances for a sustainable peace.

\subsection{Operational Policy 2.30: Development Cooperation and Conflict}

OP 8.00 has to be read together with Operational Policy and Bank Procedures 2.30 on Development Cooperation and Conflict (OP/BP 2.30) that set out the guiding principles for the Bank's engagement in conflict-affected countries. ${ }^{25}$

This policy finds its origins in the 1997 Framework for the World Bank Involvement in Post-Conflict Reconstruction. ${ }^{26}$ Until then, in fact, apart from emergency lending, the Bank dealt with conflict-affected countries taking a case-by-case approach. ${ }^{27}$ This changed only in 1997, when the Framework was developed in consultation with UN agencies and other donors, NGOs and representatives of conflictaffected countries and later endorsed by the IBRD/IDA Executive Boards.

The document outlined a five-phased approach to post-conflict situations: the first phase consisted in the preparation of a watching brief for countries in which the Bank was not yet involved; afterwards, the Bank would collaborate with the government in drafting a transitional support strategy to be followed as soon as possible by early reconstruction activities; then, the Bank would provide emergency recovery assistance before finally returning to normal operations.

In 2001, the Framework was replaced by OP and BP 2.30, which are still in force (as lastly revised in July 2015). At the outset, OP 2.30 recognizes that economic and social stability and human security are prerequisites for sustainable development and that the gains of development can be easily reversed by 
violent conflict.

Based on these premises, the policy clarifies the purposes and level of the Bank's involvement (BP 2.30.1). For countries deemed vulnerable to conflict, the Bank will use its standard instruments to minimize potential causes of conflict. For countries experiencing a conflict, the Bank will continue lending (as defined in a Country Partnership Framework) when possible, analysing the impact of conflict on economic and social development. When the intensity of the conflict prevents the Bank to continue delivering assistance in line with the Country Partnership Framework, a watching brief to monitor the evolution of the socio-economic situation on the ground will be initiated (BP 2.30.2). This will help the Bank to be ready to deliver assistance as soon as opportunities arise. In countries in transition from conflict, the Bank will support recovery and development with particular attention to war-affected groups.

In undertaking its activities the Bank should be guided by three important principles (OP 2.30.3). First, it has to act within its own mandate, while the UN (and some regional organizations) will take the lead in peace making and peacekeeping activities. The Bank may participate in these activities in collaboration with UN agencies and on the basis of the World Bank-UN Partnership Framework for Crisis and PostCrisis Situations, signed in $2008 .^{28}$ Usually the Bank does not finance political reconciliation processes or the organizations of elections or the disarmament of combatants, however, it has often contributed to the reintegration of ex-combatants, social and economic stabilization programs, leadership training and State building. 29

Second, the Bank must respect the political prohibition set forth in the Articles and refrain 'from interfering in the domestic affairs of a member or from questioning the political character of a member' (OP 2.30.3.b); it follows that assistance can be provided only upon a member's request and that the Bank cannot operate in the territory of a member without its consent ${ }^{30}$; however, when no government is in power, the policy stipulates that the Bank's engagement may be initiated 'by requests from the international community, as properly represented (e.g., by UN agencies), subject in each case to the prior approval of the Executive Directors' (OP 2.30.3.b).

Third, the Bank's resources and facilities can be used only for the benefit of its members. ${ }^{32}$

\subsection{The World Bank's Assistance to Fragile and Conflict-Affected Countries}

Every year since 2006 the World Bank publishes the Harmonized List of Fragile Situations. ${ }^{33}$

The list includes countries or territories ${ }^{34}$ having either: 'a) a harmonized Country Policy and Institutional Assessment (CPIA) ${ }^{35}$ rating of 3.2 or less; or b) the presence of a UN and/or regional peace-keeping or political/peace-building mission during the last three years' (with the exclusion of borders monitoring missions). ${ }^{36}$ Out of the 35 countries currently classified as FCSs (FY2016) 27 are IDA-eligible; among these, 17 are situated in Africa.

IDA plays a central role in providing assistance to fragile and conflict-affected States and since 2000 it has disbursed over $\$ 28.5$ billion to these countries. The Bank's support was aimed at building State capacity (supporting public expenditure management, procurement capacity and integrity, civil service reforms and revenue collection and management), at building capacity of citizens (financing projects on health and education, community driven development, demobilization, disarmament and reintegration as well as justice reform), at promoting inclusive growth and jobs (especially in the transport, energy and mining sectors), and at tackling gender disparities. 37 
IDA lends at highly concessional terms and is funded mainly through contributions from its richer members, which every 3 years replenish its resources. ${ }^{38}$ However, the amount of funds available, which is fixed after each 'replenishment', is not enough to meet the needs of eligible countries. ${ }^{39}$ Therefore, IDA distributes its scarce resources among members according to predefined allocation criteria (a minimum base allocation is guaranteed to all eligible countries). The allocation of IDA funds is generally based on the income levels and population size of the recipient country, as well as on its performance and track record in implementing IDA projects.

As for FCSs, they can receive IDA financing in the form of regular allocations ${ }^{40}$ or through special allocations. ${ }_{42} 1$ The latter consist of two windows, respectively for post-conflict countries or re-engaging countries.

A post-conflict country can either be emerging from a severe and long-lasting conflict or from a short but highly intensive conflict, or be a newly sovereign State emerged through the violent break-up of a former entity. Its eligibility to receive a special IDA allocation is assessed on the basis of the extent of human casualties, the number of internally displaced persons and the amount of physical destruction. Support is provided for a period of 10 years, which include a phasing out of 6 years to move to regular allocations.

A re-engaging country is a State that had experienced a prolonged disengagement period from IDA, but that expressed its willingness to re-engage based on a strong transition program with concerted donor support. Eligibility to receive special allocations is determined by evidence of partial State collapse and the accumulation of huge arrears. Support is provided for a period of 5 years, which include a phasing out of 3 years to move to regular allocations.

In both cases, the provisions of OP 2.30 apply.

The two aforementioned special regimes were introduced in recognition of the exceptional challenges faced by post-conflict and re-engaging countries. However, the special regimes 'were structured around the conflict/post conflict paradigm under which countries were assumed to follow a linear transition from violence to peace [...] As shown in the 2011 World Development Report, the path out of fragility is often very long and non-linear, with countries experiencing periods of progress interrupted by cycles of repeated violence and instability'. 43

In recognition of these shortcomings, participants in the IDA17 Replenishment agreed to raise the share of IDA financing to fragile and conflict-affected countries by $50 \%$. In addition, they endorsed some changes to the IDA's regular allocations system (increasing its poverty-orientation and reducing the relevance of the borrower's performance) and decided for an extension of the phasing-out period under the postconflict and re-engaging regimes acknowledging that the transition out of fragility can vary significantly from country to country.

Moreover, starting from IDA17, a new exceptional regime was introduced to provide support to countries facing 'turn-around' situations. For these purposes, a 'turn-around situation' is defined as 'a critical juncture in a country's development trajectory marked by: (1) the cessation of an ongoing conflict (e.g., interstate warfare, civil war or other cycles of violence and/or partial State collapse that significantly disrupt a country's development prospects); or (2) the commitment to a major change in the policy environment either following a prolonged period of disengagement from Bank lending (i.e., re-engaging countries) or a major shift in a country's policy priorities'. 44 These countries will be eligible for exceptional allocations if significantly affected by conflict or State collapse and only as long as they commit to take action. The duration of support is aligned with the national transition plan. 
Besides IDA's lending, FCSs are usually financed through Global Trust Funds (like the State-and Peace Building Fund) or Multi-Donor Trust Funds ${ }^{45}$ (like the Sudan Multi-Donor Trust Fund and the Liberia Reconstruction Trust Fund).

The State- and Peace-Building Fund (SPBF) was established in 2008 with a mandate to support: (a) measures aimed at improving governance and institutional performance in countries emerging from, in, or at risk of sliding into, crisis or arrears; (b) the reconstruction and development of countries prone to, in, or emerging from conflict.

Financing from the SPBF is available to all Bank members (including countries in arrears), with priority given to fragile situations (as listed), countries experiencing violent conflict or that had experienced conflict in the past 10 years, countries at risk of falling into arrears or relapsing into conflict, and countries in a transition process that receive insufficient IDA grants.

Often, intervention of the SPBF opens the doors for IDA operations: for instance, financing countries in arrears or providing small grants for urgent activities not easily funded under regular IDA credit or grant operations.

The creation of the SPBF followed by 2 years that of the UN Peacebuilding Fund (PBF). ${ }^{47}$ While the SPBF successfully catalysed new resources to fill funding gaps for countries in the Peacebuilding Commission agenda, in practice it competed to attract the same donors. 'Dissatisfaction among donors with the speed and coherence of the PBF's first 2 years of grant making arguably benefits the Bank's SPBF [...] The PBF's failures contributed to a diversification, not a consolidation, of financing instruments - the opposite of coordination and coherence'. 48

\section{The IMF's Role in Post-Conflict and Fragile Countries}

Until the 1990s, the IMF engaged with post-conflict countries through its usual instruments: surveillance, staff monitored programs, technical and financial assistance. ${ }^{49}$

It was only in 1995 that the IMF, recognizing their specific vulnerabilities and needs, adopted the Emergency Post-Conflict Assistance policy (EPCA).

In 2009, however, after the reform of the IMF concessional lending architecture, the EPCA policy was superseded by the Rapid Credit Facility (RCF) and, as of today, the IMF has not established yet an ad hoc facility to provide financial assistance for FCSs, differentiating fragile countries from other low- or middle-income members.

This chapter describes the instruments applied by the IMF in post-conflict situations and in, particular, staff monitored programs, the Emergency Post-Conflict Assistance policy and the Rapid Credit Facility. Special attention will be paid to the role the IMF has played in African countries where a UN peacekeeping mission was being deployed.

\subsection{Staff Monitored Programs (SMPs)}

Staff monitored programs are applied by the Fund when a borrowing arrangement with a country is not feasible. On the basis of an informal agreement, the Fund staff closely monitors the implementation of the country's economic program and meets regularly with national authorities to discuss progress in achieving 
predefined targets. Through this instrument, the Fund helps the country establishing a track record of good performance before discussions on a loan arrangement begin.

SMPs do not entail a formal endorsement of the country's policies by the IMF Executive Board or any kind of resource commitment from the Fund. Rather, they provide the Fund with a tool to review a member's economic situation and provide policy advice outside the context of Article IV consultations or of an IMF-supported program.

SMPs can be resorted to when the country has a limited institutional capacity or it experiences domestic instability, needs to clear its payment arrears towards the Fund ${ }^{51}$ or when a previously negotiated IMFsupported program has gone off-track.

Their purpose is to help a member State establishing a track record of policy implementation that could pave the way for the provision of emergency assistance, the conclusion of a standard financial arrangement, or the resumption of an existing arrangement.

SMPs are not made subject to conditionality requirements, but are based on a quantitative macroeconomic framework and include quarterly performance benchmarks. Their normal duration is 6-18 months, to be extended in special circumstances if performance is not satisfactory. The features of the country's economic program are usually outlined in a letter of intent.

This non-financial arrangement became an important instrument in the IMF toolkit at the end of the 1990s (when an internal guidance note on their use was adopted), but it is still in use today.

In many cases, to keep momentum of policy reform, recourse to SMPs was reiterated for subsequent periods of time. After undergoing SMPs, most of the countries moved to a regular IMF-supported program.

The following examples will help understanding the scope and impact of SMPs having special consideration to African countries.

In the case of Liberia, a country torn apart by prolonged periods of civil war (1989-1996 and 2000$2003)^{52}$ and with outstanding payments arrears towards the Fund, an SMP could be started only in 2006 after democratic elections. ${ }^{53}$ The key objectives of the SMP were to rebuild public institutions, restore a credible financial management and accelerate structural reforms. Thanks to the successful implementation of the SMP, ${ }^{54}$ Liberia moved to a Poverty Reduction and Growth Facility (PRGF) arrangement in 2008 and received debt relief under the Heavily Indebted Poor Countries initiative (HIPC) ${ }^{55}$ in 2010 after clearing its arrears with the Fund.

In 2002, the Central African Republic - being unable to complete a PRGF program due to the worsening security conditions - requested to undergo an SMP. Notwithstanding the country's reform efforts, conflict and instability persisted. The country later received EPCA assistance in two occasions: in 2004, after a coup d'état, and in 2006, while fighting between the Government and rebel forces resumed.

The Democratic Republic of Congo received emergency assistance in 1998 and 2000. At the expiration of the latter program, however, the Fund considered more appropriate to keep a close dialogue with the country authorities through a series of SMPs (2001-2002, 2003,2004), instead of negotiating a standard financial arrangement. The SMPs were followed by a PRGF only in 2004 (at the same time of the deployment of the MONUC peacekeeping operation). ${ }^{56}$ 
Sudan agreed on a first SMP in 2010, but the reform process was halted when, after years of ethnic conflicts culminating in the Darfur genocide, ${ }^{57}$ South Sudan seceded from Sudan in $2011 .^{58}$ The economic situation worsened considerably because of a heavy debt burden, international sanctions, insecurity conditions, macroeconomic imbalances and a strong dependency on oil revenues. A new SMP was therefore adopted in $2014^{59}$ with the goals of restoring macroeconomic stability, strengthening social safety nets, and creating condition for sustainable and inclusive growth. The program also aimed at bringing Sudan's external debt to a sustainable level and clearing arrears with multilaterals on the path to obtain debt relief under the HIPC initiative and from bilateral official and commercial creditors.

\subsection{The Introduction of the Emergency Post-Conflict Assistance Policy}

After the crises of the early 1990s (the first Gulf War, the collapses of the Soviet Union and of the Socialist Federal Republic of Yugoslavia, the genocide in Rwanda), the 1995 G7 Heads of State or Government met in Halifax and called on 'the Bretton Woods institutions and the UN to establish a new coordination procedure, supported as necessary by existing resources, to facilitate a smooth transition from the emergency to the rehabilitation phase of a crisis, and to cooperate more effectively with donor countries'.60

As a result, and not without controversy, in 1995 the IMF adopted the Emergency Post-Conflict Assistance policy (EPCA), broadening the scope of its emergency assistance, originally intended only to help countries hit by natural disasters, to include member States emerging from civil unrest or international armed conflict.

The decision to introduce a special lending policy, rather than creating a facility, ${ }^{61}$ was not taken unanimously: several Executive Directors argued that the provision of post-conflict assistance-that fell within the primary responsibilities of aid agencies and multilateral development banks - would threaten the monetary character of the IMF. ${ }^{62}$ It was recognized however that both natural disasters and conflicts caused temporary negative shocks and severe economic imbalances, requiring a relatively short period of emergency assistance before a standard IMF arrangement could be negotiated.

Eligible to borrow under the EPCA were only post-conflict countries lacking the institutional and administrative capacity to develop and implement a comprehensive IMF-supported program and facing an urgent balance of payments need. A demonstrated commitment on the part of the authorities and sufficient capacity for policy planning and implementation was nonetheless required by the Fund as an adequate safeguard for the use of its resources.

EPCA assistance was essentially aimed at rebuilding external reserves and meeting essential external payments (including payments to multilaterals), ${ }^{63}$ but it focused also on reinforcing the country's administrative and institutional capacity. Performance under an EPCA program was also taken into account in assessing the country's eligibility to receive debt relief under the HIPC initiative.

Initially, access was limited to $25 \%$ of the quota, to be increased to $50 \%$ only under exceptional circumstances. Since the loan was to be quickly disbursed in a single credit tranche, conditionality could be applied only in the form of prior actions. ${ }^{64}$ In 2004, though, the Executive Board extended the length of EPCA supported programs up to 3 years and decided that the loans could be disbursed in two or more tranches to help ensure the effective use of Fund resources and provide an incentive to develop a comprehensive economic program. ${ }^{65}$

National authorities were not required to produce a formal letter of intent, but conditions for EPCA 
assistance included a description of the country's economic policies, a quantified macroeconomic framework (to the extent possible) and a statement from the authorities to be ready to move as soon as possible to a standard arrangement with the Fund.

In the G7 vision, the Fund's support would be part of a concerted international effort, playing a catalytic role by attracting support from other official donors. The Executive Directors however implicitly excluded that the IMF would ever be the leading organization, deeming sufficient the "early preparation, where possible, by the affected member and the lead agency, in consultation with other relevant agencies and bilateral donors and creditors, of a framework paper for organizing technical assistance and financial support'. ${ }^{66}$ In the Fund's practice, however, strategic coordination with other international organizations and agencies was set aside.

Even if the first country to borrow under the EPCA policy was Bosnia and Herzegovina, ${ }^{67}$ between 1995 and 2005 the IMF emergency post-conflict assistance was mainly directed at African countries. ${ }^{68}$ Most of them had previously undergone an SMP.

After the genocide, in 1997 the IMF re-engaged in Rwanda through two EPCA loans focusing on institutional capacity-building and the reintegration of refugees and internally displaced persons. The Fund also supported the implementation of structural reforms such as strengthening the National Bank of Rwanda, establishing a public revenue authority and introducing a value-added tax. Economic performance and progress in structural reforms made possible for the country to move to a 3-year arrangement under the Enhanced Structural Adjustment Facility (ESAF) in 1998.

As for the Republic of Congo, the IMF provided EPCA loans in 1998 and 2000, even if the country situation was highly unstable due to the continuous resumption of internal conflicts; the key priorities under the EPCA were strengthening the country's administrative capacity and improving the macroeconomic framework.

Sierra Leone and Guinea-Bissau respectively borrowed from the Fund in 1998 and in 1999 after the restoration to power of a civilian government. In the case of Guinea-Bissau, the EPCA-supported program focused on reintroducing regular budgetary procedures and on identifying and clearing domestic arrears.

In 2002 Burundi received EPCA after emerging from conflict in 2000.

In the 2 years following the start of the program, on average, these countries experienced real GDP per capita growth, lower inflation rates and reduced external and fiscal imbalances. ${ }^{69}$ In most of the cases, EPCA loans provided bridge financial assistance before the country was ready for larger and longer-term ESAF or PRGF lending. ${ }^{70}$ However, because of deep institutional weaknesses and continuous instability, transition from EPCA to standard arrangements varied greatly, taking up to 3 years. ${ }^{71}$ Besides, performance under the first ESAF or PRGF program was not always satisfactory.

Overall, EPCA programs were mainly aimed at capacity building and at strengthening growth and macroeconomic stability. Policies were focused on lowering inflation rates, raising domestic revenues, increasing spending on urgent post-conflict needs and achieving debt sustainability.

Usually, structural reforms (such as banking sector reforms, privatizations, rebuilding of public infrastructures, reform of the security sector and the judiciary) were part of conditionality requirements only under subsequent standard IMF-supported programs. 


\subsection{The New Architecture of the IMF Concessional Facilities}

In 2010, the IMF reformed its concessional lending facilities with a view to make support to low-income countries more flexible and tailored to their specific and diverse needs. ${ }^{72}$ Under the new architecture, emergency assistance policies were replaced by the Rapid Financing Instrument (RFI) and the Rapid Credit Facility (RCF).

While the RFI is available to all member countries, only low-income countries are eligible to receive assistance under the RCF. The two instruments are highly similar in that both can be accessed by countries facing urgent balance of payments needs - caused by exogenous shocks, natural disasters, conflict, domestic instability, other emergencies or fragility - , for which a standard Fund-supported program is not necessary or not feasible. The latter case arises when the country has only a limited institutional capacity or experiences protracted domestic fragilities.

Financial assistance under the RCF is provided in a single and up-front disbursement, but a repeated use of the facility is possible. Only a limited conditionality is attached (usually in the form of ex-ante policy undertakings) and no program reviews are foreseen.

The RCF is designed to streamline the Fund's emergency assistance, placing more emphasis on poverty reduction and growth. The letter of intent accompanying a request for RCF financing should describe how the RCF-supported policies would advance the country's poverty reduction and growth objectives. Social spending should be safeguarded and, whenever appropriate, increased.

Since 2011, RCF lending has been delivered to low-income fragile countries, de facto replacing SMPs. ${ }^{73}$

The case of the Central African Republic might be used as an example. The country experienced a new political and security crisis in 2013, when the Libreville Peace Agreement was breached. ${ }^{74}$ Months of violence led to the collapse of the economy, leaving millions of people starving and in urgent need of humanitarian aid. In 2015, the IMF finally approved the disbursement of financial assistance under the RCF facility. The program was designed to enhance macroeconomic stability, advance fiscal consolidation and coordinate technical assistance, while securing the commitment of international donors for continued assistance.

\subsection{The Review of the Fund's Engagement in Post-Conflict and Fragile Countries}

In recent years, the growing recognition by the international community that conflict and fragility are the

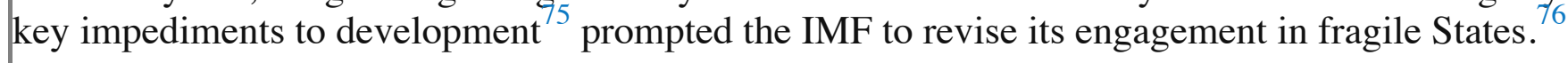

The IMF considers 'fragile' those States having weak institutional capacity in the political, security and economic sectors (as measured by World Bank indicators) ${ }^{77}$ and/or that experienced a period of conflict (signalled by the presence of a peace-keeping or peace-building operation in the most recent 3-year period).

The majority of fragile countries are situated in Africa and the challenges they pose are immense. Their economic performance is weak as well as their ability to deliver basic social services. They are likely to have negative spill-overs on neighbouring countries (for instance, because of refugee flows or humanitarian crises). They are usually overborne by high levels of debt and protracted payments arrears and unable to attract external assistance and investments. Moreover, even when rich of natural resources, 
this results in violence, corruption, mismanagement and the enrichment of very few (this phenomenon is usually described as the 'resource curse').

Despite their specific needs and challenges, the Fund did not modify its long-established practice of not differentiating fragile countries from low- or middle-income members. In fact, apart from the EPCA policy (which is not an IMF facility), the Fund never introduced a special lending instrument available to FCSs only.

Consistent with this approach, in 2012 the Fund adopted a guidance note outlining the principles for its engagement with fragile countries. ${ }^{79}$ The main recommendations for the Fund's staff are the following: in giving its policy advice, the Fund should focus on policy measures that increase social cohesion and that do not place undue stress on the political and social fabric; the pace of macroeconomic adjustment should be carefully tailored to the country specificities and should not be overambitious, with a proper sequencing of reforms; attention should be paid to job creation and the preservation of social expenditure (in particular social safety nets), with a view to overcome social cleavages; capacity-building support should be implemented in close coordination with other development partners, such as the World Bank; and, last but not least, the reform agenda needs to be endorsed and owned by the government.

In July 2015, the IMF's work in FCSs was discussed in the framework of the Third UN Conference on Financing for Development which was held in Addis Ababa. ${ }^{80}$ In this context, the Executive Directors welcomed proposals to strengthen the Fund's non-financial support for fragile and conflict-affected states, to be focused on building institutional capacity over the medium term. ${ }^{81}$

\section{Conclusions}

Despite the interdependent role of the UN, the IFIs, other international organizations and donors in Stateand peace-building has long been recognized, financing remains scarce and volatile and coordinated action insufficient.

Shortfalls in donor funding are particularly serious for most of the countries where UN peace operations are deployed. ${ }^{82}$ Moreover, overlaps, duplications and discontinuities between humanitarian, development, security and State- and peace-building initiatives are common and seem difficult to overcome.

While, on the one hand, the 2008 UN-World Bank Partnership Framework constituted an important step in fostering the development of best practices and effective cooperation, on the contrary, the IMF's collaboration with other actors remains mainly limited to information sharing.

According to the 2015 Report of the Advisory Group of Experts on the Review of the Peacebuilding Architecture titled The Challenge of Sustaining Peace: 'Current efforts to promote post-conflict economic recovery are relatively timid and appear to cluster around a three-track approach: immediate stopgaps (such as emergency employment programs), early recovery (broadly aimed at recovery of incomegenerating capacity) and longer-term economic recovery (such as economy-wide reforms for enabling growth). There is, however, little clarity in either research or practice on re-energizing economies. The usual phase of brisk post-conflict economic rebound proves difficult to sustain'.

Therefore, there is an urgent need to make cooperation among the UN, the World Bank and the IMF on peace- and State-building issues more systematic, especially at the operational level. Accordingly, the UN Security Council is called by the authors of the Report to include 'in all mandates with peace-building dimensions an explicit reference to the need for consultation and collaboration between the United 
Nations and the IFIs in planning and prioritization at the country level'. ${ }^{4}$

Moreover, UN agencies (in particular the Peacebuilding Commission) should strengthen collaboration with the World Bank on key themes (priorities identified during the IDA17 replenishment exercise include jobs and livelihoods, strengthening public sector capacity in FCSs, and promoting justice sector reform) ${ }^{85}$ and to engage in regular policy dialogue with the IMF on the fiscal and macroeconomic dimensions of peace-building. 86

\section{References}

Adinolfi G (2012) The role of international financial institutions. In: De Guttry A, Gestri M, Venturini G (eds) International disaster response law. Asser, The Hague, p 601 et seq

Besley T, Persson T (2011) Fragile States and Development Policy. CEPR Discussion Papers 8285

Boisson de Chazournes L (2000) Policy guidance and compliance: the World Bank operational standards. In: Shelton D (ed) Commitment and compliance: the role of non-binding norms in the international legal system. OUP, Oxford, p 281 et seq

Boon KE (2007) Open for business: international financial institutions, post-conflict economic reform, and the rule of law. N Y Univ J Int Law Polit 39:513 et seq

Boughton JM (2012) Tearing down walls: the International Monetary Fund 1990-1999. IMF, Washington

Cellamare G (2011) Osservazioni sulle disposizioni in materia di ricostruzione e di governance dell'economia contenute in risoluzioni del Consiglio di Sicurezza dell'ONU. In: Ligustro A, Sacerdoti G (eds) Problemi e tendenze del diritto internazionale dell'economia - Liber amicorum in onore di Paolo Picone. Editoriale Scientifica, Napoli, p 31 et seq

Cissé H (2012) Should the political prohibition in charters of international financial institutions be revisited? The case of the World Bank. In: Cissé H, Bradlow D, Kingsbury B (eds) The world bank legal review volume 3: international financial institutions and global legal governance. The World Bank, Washington, p 59 et seq

Coffey P, Riley RJ (2006) Reform of the international institutions: the IMF, World Bank and the WTO. Edward Elgar, Cheltenham

Collier P (2007) The Bottom billion: why the poorest countries are failing and what can be done about It. OUP, New York

Collier P (2009) The Political Economy of Fragile States and Implications for European Development Policy, at erd.eui.eu

Collier P, Hoeffler A (1998) On economic causes of civil war. Oxf Econ Papers 50:563 et seq

Collier P, Hoeffler A (2004) Aid, policy and growth in post-conflict countries. Eur Econ Rev 48:1125 et seq 
Collier P, Sambanis N (eds) (2005) Understanding civil war: evidence and analysis. World Bank, Washington

Collier P et al (2003) Breaking the conflict trap: civil war and development policy. World Bank, Washington

Collier P, Hoeffler A, Söderbom M (2008) Post conflict risks. J Peace Res 45:461 et seq

European Commission (2009) Overcoming fragility in Africa, in European report on development, Robert Schuman Centre for advanced studies. European University Institute, Florence

Jenkins R (2013) Peacebuilding: from concept to commission. Routledge, London

Kapur D, Lewis JP, Webb RC (1997) The World Bank. The Brookings Institution, Washington

Kreimer A et al (1998) The World Bank's experience with post-conflict reconstruction. World Bank, Washington

Mason ES, Asher RE (1973) The World Bank since Bretton Woods. The Brookings Institution, Washington

Ragazzi M (2001) The role of the World Bank in conflict-afflicted areas. ASIL Proc 95:240 et seq

Shihata I (1991) The World Bank in a changing world. Martinus Nijhoff, Dordrecht

Staines N (2004) Economic performance over the conflict cycle. In: Jap C (ed) Postconflict economy in Sub-Saharan Africa: lessons from the democratic Republic of the Congo. IMF, Washington, p 159 et seq

Tschirgi N (2004) Post-Conflict Peacebuilding Revisited: Achievements, Limitations, Challenges, at www.un.org

Collier and Hoeffler (1998). See also Collier et al. (2003), Collier and Hoeffler (2004), Collier and Sambanis (2005), Collier (2007), Collier et al. (2008).

Collier (2009).

Economic growth can be spurred by increased commodity exports, resource extractions and investment in infrastructure.

See Tschirgi (2004), Adinolfi (2012).

The terms 'World Bank' or 'Bank' are used as shorthand for the IBRD, alone or in conjunction with the IDA, established in 1960 to provide concessional funding for low-income and poor countries. The term 'World Bank Group' also includes the IFC, the MIGA and the ICSID.

6

On the UN Security Council resolutions dealing with the economic reconstruction and economic governance reform of postconflict countries see Cellamare (2011).

According to Boon (2007) at pp. 513-515, in this way the IFIs have exercised broad de facto legislative powers 'that have pushed their de jure mandates into domestic matters normally reserved to sovereign States. These expanding post-conflict activities illustrate the increasing relevance of IFIs not only to domestic law and legal reform but more broadly to international peace and security'. 
The Peacebuilding Commission is composed of 31 member States. Representatives from the World Bank, the IMF and other institutional donors are invited to participate in its meetings; see para. 9 of the founding resolutions A/RES/60/180 and S/RES/1645(2005).

9

10

The $\mathrm{g} 7+$ is a group composed of 20 fragile and conflict-affected States.

The Dialogue is a forum bringing together countries affected by conflict and fragility and their international development partners. They meet to identify more effective ways to assist FCSs in their recovery path.

In 2011, the New Deal for Engagement in Fragile States was endorsed by 44 countries and international organisations, during the 4th High Level Forum on Aid Effectiveness in Busan, South Korea. The New Deal identifies five peace-building and Statebuilding goals (legitimate politics, security, justice, economic foundations and revenue and services) that should be included in the post-2015 development agenda. It recommends to 'focus' on country-led fragility assessments, on supporting nationally led and owned development strategies, and on building consensus around a compact. The New Deal also aims to increase 'trust' between national and international actors by promoting transparency of aid, risk-sharing, capacity development and the delivery of timely and predictable external aid.

12

Available at web. worldbank.org .

Article I of the IBRD Articles of Agreement. On the history of the World Bank see: Mason and Asher (1973), Shihata (1991), Kapur et al. (1997), Coffey and Riley (2006).

14

See Cissé (2012), p. 59 et seq.

The WB Operational Manual provides guidance to the staff determining standards for the conduct of Bank operations.

See Boisson de Chazournes (2000), p. 281 et seq.

The Inspection Panel is an independent complaint mechanism set up by the IBRD/IDA in 1993. Complaints can be submitted to the Panel by at least two persons or a community who claim that they have been, or are likely to be, adversely affected by a project funded by the World Bank.

18

See Kreimer et al. (1998)

OP 8.50 listed among the excluded relief activities: search and rescue, evacuation, food/water distribution, temporary sanitation and health care, temporary shelter, and restoration of access to transport.

20

The World Bank (2007) Toward a New Framework for Rapid Bank Response to Crises and Emergencies; see also The World Bank (2007) Strengthening the World Bank's Rapid Response and Long-term Engagement in Fragile States (SecM2007-001S); IEG (2006) Engaging with Fragile States: An IEG Review of World Bank Support to Low-Income Countries Under Stress. 21

In 2014, the OP 8.00 was revised to take into account the fact that the WB adopted a new approach to country engagement and is replacing Country Assistance Strategy papers with Country Partnership Framework (see the World Bank, IFC, MIGA, World Bank Group: A New Approach to Country Engagement, 29 April 2014, doc n. 87846). The World Bank's Operational Policy on Development Cooperation and Conflict (OP/BP 2.30) was last revised in 2014.

The World Bank Operational Manual, Operational Policies, OP 8.00 Rapid Response to Crises and Emergencies, March 2007, as revised in July 2014

See Legal Opinion on Peace-building, Security, and Relief Issues under the Bank's Policy Framework for Rapid Response to Crises and Emergencies, 22 March 2007, published as an annex to The World Bank (2007) Toward a New Framework for Rapid Bank Response to Crises and Emergencies, p. 37.

24

The World Bank (2009) Rapid Response to Crises and Emergencies (OP 8.00): Progress Report, pp. 3-4. See also World Bank (2007) Cote d'Ivoire - Post-Conflict Assistance Project, p. 4; World Bank (2008) Uganda - Emergency Demobilization and Reintegration Project, p. 2, both available at documents. worldbank.org . 25

The OP/BP 2.30 are both available at policies. worldbank.org . On OP/BP see also Ragazzi (2001), pp. $240-245$. 26

The document Post-Conflict Reconstruction: The Role of the World Bank (Washington, DC: World Bank, 1997) was endorsed by the Executive Directors as A Framework for World Bank Involvement in Post-Conflict Reconstruction, May 1997. 
$\angle l$

In order to decide whether to lend or continue lending to conflict-affected countries, the Bank used to assess the country's ability to repay, its capacity to realize the project and the benefits it would receive. The safety of the Bank staff was also taken into account. See Cissé (2012), p. 59 et seq.

28

According to the UN-World Bank Partnership Framework for Crisis and Post-Conflict Situations, the roles of the UN and of the World Bank are interdependent and mutually reinforcing. Therefore, integrated efforts 'are particularly important in working with national authorities and partners to strengthen national capacity for effective prevention and response and to support the implementation of national recovery and development strategies that encompass political, security, human rights, economic and social dimensions within the framework of the rule of law and good governance'. In post-crisis settings, the UN-WB partnership will be strengthened in the areas of regular communications, participation in 'respective planning processes and the development of shared benchmarks/results frameworks and joint processes for monitoring and review', and financing policies and procedures. In 2010, to break institutional barriers and strengthen collaboration, in line with the principles outlined in the UN-World Bank Partnership, the UN-World Bank Fragility and Conflict Partnership Trust Fund was set up. 29 30

See Cissé (2012), p. 67 and for some examples fn 49.

OP/BP 7.30 Dealings with De Facto Governments has to be applied when a de facto government comes into or remains in power by means not foreseen in the country's constitution. The Bank's continuous engagement is subordinated to the following conditions: the de facto government is in effective control of the country, it recognizes past international obligations and is willing and able to assume its predecessors' obligations towards the Bank as well as to implement the project/program. The Bank should carefully evaluate whether to extend a new loan to the country. Dealing with de facto governments does not in any sense constitute an approval of the government. Pursuant to the political prohibition enshrined in the Articles of Agreement, the Bank's decisions cannot be influenced by the political character of the member country concerned.

31

This provision was applied in the case of Kosovo, before it became member of the IBRD and the IMF in 2009, and the West Bank and Gaza. In the latter case, special arrangements are in place since 1993, when a Trust Fund was established as a mechanism for funding assistance.

Exceptionally, the Bank has provided assistance to non-member States (like in the case of Kosovo, before it acquired membership in the IMF and the IBRD/IDA). Assistance to non-member countries was extended on the basis of the consideration that it would benefit the Bank's members in line with the wording of IBRD Article III.1.a ('the resources and the facilities of the Bank shall be used exclusively for the benefit of members' emphasis added). See Boon (2007), p. 571. 33

The list was once called the Low-Income Countries Under Stress (LICUS) List. In 2010, it was 'harmonized' to average the World Bank CPIA scores with those of regional development banks.

34 35

Reference is made to the West Bank and Gaza.

The CPIA aims to assess a country's performance in implementing policies that promote economic growth and poverty reduction. The CPIA rating is calculated against a set of 16 criteria grouped in four clusters: economic management, structural policies, policies for social inclusion and equity and public sector management and institutions. For each of the 16 criteria, countries are rated on a scale of 1 (low) to 6 (high).

36

The list includes IDA-eligible and blend countries. IBRD-only countries are listed if a peacekeeping or peace-building mission is deployed in their territory. CPIA ratings of IBRD-only countries in fact are usually not disclosed. 37 38

IEG (2014) World Bank Group Assistance to Low-Income Fragile and Conflict-Affected States: An Independent Evaluation.

39 The last replenishment (IDA17) was finalized in December 2013 to finance projects until June 2017.

Eligibility for IDA support is primarily determined by a country's relative poverty. Currently 77 countries whose GNI per capita is below USD 1215 (for the fiscal year 2016) are eligible to receive IDA assistance. A second criterion used to determine

eligibility to access IDA resources is the lack of creditworthiness to borrow at market terms.

Regular allocations are based on the Performance Based Allocations system. Performance is measured by the Country Policy and Institutional Assessment (CPIA) and the Portfolio Performance Rating (PPR). 41

Special allocations are based on the Post-Conflict Performance Indicators (PCPI) framework. The PCPI is organized around four clusters: economic management and structural policies; social inclusion and human development; governance; and postconflict risk. All four clusters are used to assess the performance of post-conflict countries, while the first three only are used to 
evaluate re-engaging countries.

For the FY15 exercise, the countries eligible to receive post-conflict exceptional allocations were Afghanistan, Burundi, Côte d'Ivoire, Democratic Republic of Congo, Liberia and South Sudan, while the countries classified as re-engaging were the Central African Republic, Haiti, Myanmar and Togo.

43 44

IDA (2013) IDA17 - IDA's Support to Fragile and Conflict-Affected States, p. 17.

${ }_{45}$ Ibid., p. 20.

MDTFs are the donors' preferred tool for working in FCSs, with the Bank acting as the fund's administrator. In recent years, financing provided through MDTFs has equalled IDA funding and enabled the Bank to work in countries the IDA could not have reached at an early stage (such as Afghanistan, Bosnia, Iraq, Sierra Leone and Zimbabwe). Through MDTFs the Bank can work in areas outside its mandate (as set forth in OP 8.00), such as relief, security and some peace-building activities. 46

For a definition of State-building and peace-building as the SPF's overarching goals see World Bank (2008) Establishment of a State- and Peace-Building Fund, p. 7, available at siteresources. worldbank.org . 47

Following a request from the General Assembly (A/RES/60/180) and the Security Council—resolution 1645 (2005) - , the PBF was established in 2006 by the UN Secretary-General (UN Doc. A/60/984) to ensure the immediate release of resources critical to the peace-building process and to address gaps in that process, in particular in areas for which no other funding mechanism is available. The PBF supports the implementation of peace agreement and political dialogue, promotes peaceful coexistence and conflict resolution, and supports employment promotion and social cohesion programs. See the PBF Terms of Reference as lastly amended in 2009 (UN Doc. A/63/818).

48

49

Jenkins (2013), p. 105

We are not going to discuss in detail Article IV surveillance over post-conflict countries and technical assistance (which usually focuses on rebuilding statistical capacity, establishing and reorganizing fiscal, monetary, and exchange institutions, restoring tax and government expenditure capacity as well as payment, credit, and foreign exchange operations).

See IMF (1995) Summing Up by the Chairman-Fund Involvement in Post-Conflict Countries, Executive Board Meeting $95 / 82$.

51

52

Among others, Sudan and Liberia.

A UN peacekeeping mission (UNMIL) was established in Liberia in 2003 to monitor the implementation of the ceasefire and support the peace process; see UN Security Council Resolution 1509(2003). The UMNIL mandate was frequently revised, lastly in 2015. The mission is still operative.

See IMF (2006) Liberia: Staff Monitored Program: Letter of Intent, available at www.imf.org . A UN peacekeeping mission (UNMIL) was established in 2003 to monitor the implementation of the ceasefire and support the peace process; see UN Security Council Resolution 1509(2003). It is still operative.

Progress in the management of natural resources and adherence to the Kimberly Process Certification Scheme also led to the lifting of UN sanctions on the export of timber and diamonds.

The Heavily Indebted Poor Countries initiative was launched in 1996 and enhanced in 1999 to create a framework to provide debt relief to the poorest and most heavily indebted countries. At completion point, the country - having a track record of good performance under an IMF-supported program and after successfully completing key structural reforms - receives debt relief from the IMF and the World Bank.

56

The MONUC was established by after the signature of the Lusaka Ceasefire Agreement of July 1999 by Security Council Resolution 1279(1999). In 2010, it was renamed MONUSCO; see UN Security Council Resolution 1925 (2010).

The African Union-United Nations hybrid operation in Darfur was established in 2007-see UN Security Council Resolution 1769(2007) - and it is still in place. The birth of the Republic of South Sudan on 9 July 2011 was accompanied by the establishment of the UNMISS mission; see UN Security Council Resolution 1996(2011) and the following UN Security Council Resolution 2155 (2014).

58 59

South Sudan became the 188th member of the IMF in 2012. 
See IMF (2014) Sudan: Staff Monitored Program - Staff Report, IMF Country Report n. 14/203, available at www.imf.org .

61 See Halifax Summit Communiqué, 16 June 1995, available at www.g8.utoronto.ca .

Originally, the IMF could only provide outright disbursement to requesting countries subject to an assertion of an actual or potential balance of payments need. The practice of lending in tranches through Stand-By Arrangements was introduced in 1952 and later formalized in the 1978 Second Amendment to the IMF Articles of Agreement. Only during the 1960s, the Fund introduced a variety of special facilities to address specific balance of payments problems whenever ordinary stand-by arrangements would be inadequate or insufficient. Instead, when a special lending policy applies, the Fund establishes separate and specific criteria detailing under which circumstances it would lend through the General Resources Account (GRA). 6 63 See Boughton (2012), p. 233.

Post-conflict countries usually have outstanding payments arrears on earlier loans from multilateral institutions. 65

Prior actions have to be completed by national authorities before their request is submitted to the IMF Executive Board.

Each purchase required Executive Board approval and was subject to satisfactory progresses in institution building and macroeconomic stability, but they were not made conditional upon observance of previously defined performance criteria. 66

See IMF (1995) Summing Up by the Chairman-Fund Involvement in Post-Conflict Countries, Executive Board Meeting $95 / 82$

67

EPCA assistance for Bosnia and Herzegovina was approved on 20 December 1995 on the same day NATO forces assumed peacekeeping duties and took over from UNPROFOR.

08

69

Other countries received EPCA financial assistance: Albania, Haiti, Iraq, Serbia and Montenegro, and Tajikistan.

70

See Staines (2004), p. 159 et seq.

Post-conflict low-income countries had access to the ESAF and PRGF concessional facilities, while non low-income countries could receive support from the Fund's General Resources Account.

71

IMF (2008) The Fund's Engagement in Fragile States and Post-Conflict Countries: A Review of Experience, Issues and Options, p. 44

${ }_{73}$ See IMF (2014) Handbook of the IMF Facilities for Low-Income Countries, available at www.imf.org .

IMF (2015) Engagement with Countries in Post-Conflict and Fragile Situations - Stocktaking, pp. 19-20, available at www.imf.org .

74

Concerned with the humanitarian crisis and by revamped conflict activities, the UN strengthened in 2013 the mandate of the UN Integrated Peacebuilding Office in the Central African Republic (BINUCA) and later, in 2014, established the United Nations Multidimensional Integrated Stabilization Mission in the Central African Republic (MINUSCA); see UN Security Council Resolution 2149 (2014).

75

See OECD (2007), Principles for Good International Engagement in Fragile Situations; European Commission (2009); International Network on Conflict and Fragility (INCAF) (2010), Conflict and Fragility; OECD (2010), Peacebuilding and Statebuilding Priorities and Challenges - A Synthesis of Findings from Seven Multi-Stakeholder Consultations, International Dialogue on Peacebuilding and Statebuilding; United Nations (2010), Review of the United Nations Peacebuilding Architecture; World Bank (2011), World Development Report 2011 on Conflict, Security and Development; Besley and Persson (2011). 76

See IMF (2008) The Fund's Engagement in Fragile States and Post-Conflict Countries - A Review of Experience - Issues and Options; IMF (2011) Macroeconomic and Operational Challenges in Countries in Fragile Situations; IMF (2012) Staff Guidance Note on the Fund's Engagement with Countries in Fragile Situations; IMF (2015) Engagement with Countries in Post-Conflict and Fragile Situations - Stocktaking.

i.e. LICs are identified by the World Bank as fragile under its Fragile and Conflict-Affected States (FCS) Initiative, based on their low Country Policy and Institutional Assessment (CPIA) score (which captures the quality of economic and sectoral policies and institutions) and existence of conflict in recent years.

78

IMF Policy Paper (3 June 2015), Engagement with Countries in Post-Conflict and Fragile Situations - Stocktaking, p. 7. 
/4 80

IMF (2012) Staff Guidance Note on the Fund's Engagement with Countries in Fragile Situations.

The final text of the outcome document adopted at the Third International Conference on Financing for Development (Addis Ababa, Ethiopia, 13-16 July 2015) and endorsed by the UN General Assembly in its resolution 69/313 of 27 July 2015 is available at www.un.org . 81

IMF Policy Paper (July 2015), Financing for Development: Revisiting the Monterrey Consensus, p. 37.

UN, Report of the High-level Independent Panel on Peace Operations on uniting our strengths for peace: politics, partnership and people, UN Doc. A/70/95-S/2015/446 (17 June 2015), p. 137. 83

UN, The Challenge of Sustaining Peace-Report of the Advisory Group of Experts on the Review of the Peacebuilding Architecture, UN Doc. A/69/968-S/2015/490 (30 June 2015), p. 38. 84 85

UN, The Challenge of Sustaining Peace, p. 160.

IDA (March 2013), IDA17-IDA’s Support to Fragile and Conflict-Affected States, p. 96.

UN, The Challenge of Sustaining Peace, pp. 163-165. 